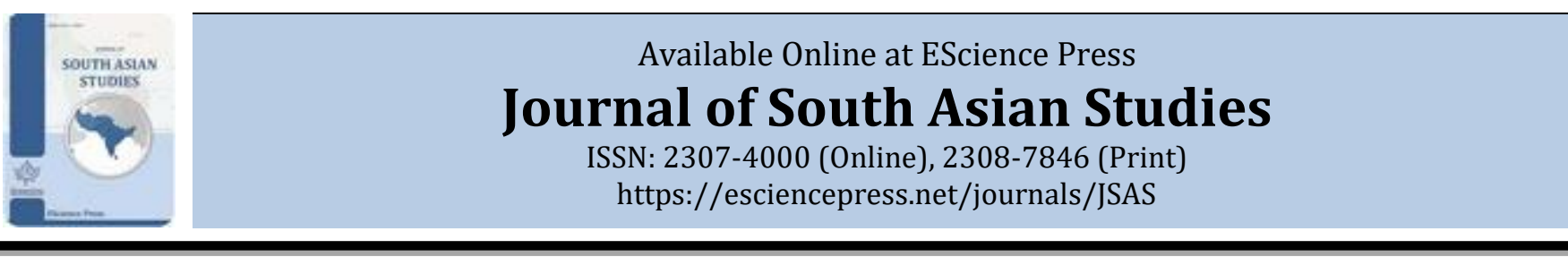

\title{
Sequential Impacts of University Students' Socioeconomic Classes, Gender, Disciplines of Study and University Education Experience on their Learning Approaches
}

\author{
aRafaquat Ali*, bFurrukh Bashir, cAbou Bakar, dIsmat Nasim \\ a Department of Education, The Islamia University of Bahawalpur, Bahawalnagar Campus, Punjab, Pakistan. \\ b School of Economics, Bahauddin Zakariya University, Multan, Southern Punjab, Pakistan. \\ c Institute of Business Management and Administrative Sciences (IBMAS), The Islamia University of Bahawalpur, \\ Bahawalpur, Punjab, Pakistan. \\ d Department of Economics, Government Sadiq College Women University, Bahawalpur, Pakistan. \\ *Corresponding Author Email ID: furrukh@bzu.edu.pk
}

\section{A B S T R A C T}

The learning approaches consist of students' learning intentions and strategies to learn. The ramification of their different learning approaches ends in various academic achievements. Their learning approaches mediate the impacts of students' epistemological beliefs, learning conceptions, personality, and ability to learn on their academic achievements. Apart from personal variables, differences in students' socioeconomic background, gender, disciplines of study, duration of experience in education, teaching approaches, and teaching methods produce differences in students' learning approaches. The cultural and social differences produce specific personal attributes in students that impact learning approaches. Therefore, this study explored the impacts of Pakistani university students' socioeconomic background, gender, study disciplines, and university education experience on their learning approaches. The sample of this study comprised 488 university students. The sampling technique to select this sample was a convenient non-probability sampling technique. The structural equation modeling approach was used to calculate the direct and total effects of students' socioeconomic background, gender, disciplines of study, and duration of university education experience on their learning approaches. The Pakistani university students' socioeconomic classes, disciplines of study, and duration of university education experience have significant direct and total effects on their learning approaches. The variable gender did not cause a significant direct or total effect on Pakistani university students' learning approaches. The study contributed knowledge regarding factors that impact university students 'learning approaches in the context of Pakistan.

Keywords: Surface Learning Approach, Deep Learning Approach, Lower Socioeconomic, Class, Middle Socioeconomic Class, Memorization, Deep learning.

\section{INTRODUCTION}

The learning approaches emphasize students' learning context understand their academic behaviors and achievements (Evans \& Vermunt, 2013). Social and cultural values determine students' epistemological and learning beliefs, and consequently, the epistemological and learning beliefs shape students' learning approaches (Biggs, 1998; Richardson, 2010). Therefore, the structure of the deep, surface and strategic learning approaches may differ in students of different cultures
(Kember, 1996; Kember \& Gow, 1990; Richardson, 1994). It is acknowledged that some critical factors in the development of learning approaches are; the disciplines of study (Nelson Laird et al., 2008), gender (Cano, 2005), students' current semester or year of education (Ismail et al., 2013), and socioeconomic background (Cano \& Cardelle-Elawar, 2008). Furthermore, assessment approaches, teaching approaches, and course perceptions also regulate students' learning approaches (Beausaert et al., 2013; 
Price et al., 2011; Scouller, 1998).

\section{LITERATURE REVIEW}

The educationists have always been interested in developing procedures and practices to ensure better learning outcomes. This aim guides educationists to understand students' interactions with learning materials. Generally, the students' characteristics such as learning or cognitive styles or their contexts of learning such as learning approaches are used to explain students' ways to teach (Evans \& Vermunt, 2013). It is constructive to understand students' decisions to approach a learning task to understand their learning practices (Duff, 2004). Therefore, the learning approaches concept helped researchers explain students' learning behaviors and learning outcomes with respect to their educational context (Case \& Marshall, 2009; Evans \& Vermunt, 2013). The learning approach integrates students' intention and the strategies to learn, and it persists during a learning situation (Biggs, 1987a). There are three types of learning approaches in literature; deep, surface, and strategic (Entwistle et al., 1979). The deep learning approach characterizes intrinsic motivation for understanding the content, and it involves strategies of relating new knowledge to existing knowledge, identifying gaps in knowledge, and structuring new knowledge (Biggs, 1987b). In comparison, the surface learning approach implicates extrinsic motivation to pass examinations and students' intention to memorize information by rehearsal or drill strategy (Case \& Marshall, 2009). The strategic learning approach characterizes organized study behaviors, time management, and the use of multiple appropriate strategies to ensure the best possible academic performance (Entwistle et al., 1979).

Learning approaches explain variance and differences in students' academic performance. The surface learning approach ends in poor academic achievements, whereas the strategic learning approach results in higher academic performance (Diseth \& Kobbeltvedt, 2010). The high academic achievers choose a strategic learning approach, and they favor teaching that supports both understanding and academic performance (Byrne et al., 2004). The deep learning approach is associated with higher academic performance (Douglas et al., 2020; Kayali et al., 2017; Salamonson et al., 2013). However, if students need memorization of facts, and course contents do not require an understanding or assessment formats are not supportive and related to deep learning, the deep learning approach may become irrelevant to students' academic performance (Byrne et al., 2004; Cetin, 2016).

Furthermore, students' learning approaches can predict their classroom behaviors. If students adopt a deep learning approach, they can explain different subjectrelated ideas and concepts, ask questions that focus on cause-and-effect explanations, and identify and resolve contradictions in their knowledge (Chin \& Brown, 2000). The students with the surface learning approach only reproduce textbook information (Chin \& Brown, 2000). Although surface learners spend long hours memorizing textbook knowledge, they fail to understand facts and information in the textbook, and consequently, they fall in examination (Kember et al., 1995). Moreover, the students who use the deep learning approach show better metacognitive skills and self-regulation of learning (Egenti, 2012; Heikkilä \& Lonka, 2006).

On the one hand, different personal and contextual factors affect students' learning approaches. For example, the students' epistemological beliefs, conceptions of learning, self-ability beliefs, cognitive ability, and personality traits determine their learning approaches (Burnett \& Proctor, 2002; ChamorroPremuzic \& Furnham, 2008, 2009; Chiou et al., 2013; Ismail et al., 2013). On the other hand, the learning approaches bond students' attributes, and contextual factors to their academic performance (Burnett \& Proctor, 2002; Chamorro-Premuzic \& Furnham, 2008).

The contextual factors also define students' learning approaches. If students perceive their course of study as heavy workload and experience a teacher-centered teaching approach, they may be inclined towards the surface learning approach (Beausaert et al., 2013; Byrne et al., 2009; Campbell et al., 2001; Kreber, 2003). However, the students may develop a deep learning approach if they learn in a student-centered teaching environment (Beausaert et al., 2013; Byrne et al., 2009; Campbell et al., 2001; Kreber, 2003). In other words, the information-transfer and teacher-centered approaches support the surface learning approach, and the conceptual change student focus approach encourages a deep learning approach among students (Rosário et al., 2013).

Likewise, different disciplines of study may foster different learning approaches. The students of Commerce, Accounting, and Business may have a higher 
likelihood of strategic learning approach (Byrne et al., 2010; Sadler-Smith, 1996). The students of Science, Biology, Biochemistry, Botany, Environmental Sciences, Microbiology, Zoology, and Mathematics may have a higher preference for surface learning approach, whereas the students of Social Sciences, English, Anthropology, Sociology, Psychology, Political Science, Ethnic Studies, and Humanities have more inclination to use deep learning approach (Ismail et al., 2013; Nelson Laird et al., 2008; Ullah et al., 2013). However, the possibility also exists that students of different subjects may not have significant differences in learning approaches (Edmunds \& Richardson, 2009).

The students' duration of experience at any educational institution also impacts their propensity for different learning approaches. The learning approaches change throughout education. Usually, university students in their first year of study do not require a deep understanding of the subject matter. Therefore, these students have a low probability of using the deep learning approach (Byrne et al., 2004). In successive years, students advance in their studies, their epistemological beliefs become sophisticated, and consequently, they have a higher tendency for a deep learning approach (Cano, 2005). In four years, degree programs, the students of the third year are found to have a greater inclination for deep learning approach than first, second and fourth-year students; however, the students of fourth and first years may use the surface learning approach more than the students of second and third years (Ismail et al., 2013).

Different studies have examined the role of demographic factors in developing learning approaches. The literature is inconclusive about the gender differences in students' learning approaches. On one side, it is found that the male students are more motivated to use the surface learning approach than female students, and female students are more inclined towards the deep learning approach than the male students (Chiou et al., 2011; Ismail et al., 2013). On the other hand, evidence supports those females have higher levels of surface learning approach than male students (Sadler-Smith, 1996). Also, some researchers have not found gender differences in students' learning approaches (Zeegers, 2001). Likewise, the student's socioeconomic background affects their learning approaches. The students of superior socioeconomic backgrounds have a high probability of using the deep learning approach because they may hold mature learning beliefs due to the better intellectual environment provided by their highly educated and professional parents (Cano \& Cardelle-Elawar, 2008).

\section{CONCEPTUAL FRAMEWORK}

The researchers have anticipated those university students' gender, field or disciplines of study, duration of university education experience, and the socioeconomic background will impact their inclinations for deep, surface, and strategic learning approaches. The students' socioeconomic background includes their parental education, occupations, income, and family expenditures. However, the researchers selected the concept of socioeconomic class to evaluate students' socioeconomic backgrounds in this study. The socioeconomic class is defined as the place of an individual within the social and economic structure (American Psychological Association, 2019). Although, occupation, education, and income are common measures of socioeconomic classes (Ensminger \& Fothergill, 2003).

The parental education and occupations are more relevant to students' academic and learning behaviors (Sirin, 2005). Therefore, the socioeconomic classes are about their parental education and occupation in this study. The researchers assigned scores to parental occupations and education by following Kuppuswamy's Socioeconomic scoring scheme (Sharma, 2017). In the case of students' learning approaches, the Noel Entwistle's model of learning approaches was adopted in this study (Entwistle et al., 1979). The conceptual framework is presented in Figure No 1.

It is conceptualized that socioeconomic classes influence university students' choice of the discipline of study, years of stay or duration of university education experience, and learning approaches. Moreover, the male and female students of different socioeconomic classes opt for various disciplines of study. The students of the same socioeconomic class may have different duration of university education experience and learning approaches because of their gender. Likewise, fields of study and university education experience also impact students' tendencies for different learning approaches.

\section{OBJECTIVES AND HYPOTHESES OF THE STUDY}

Predictably, learning approaches may differ with differences in learning, teaching, and socio-cultural context. Pakistani society has collectivistic culture, and 
teachers teach students in large groups, and students experience teacher-centered teaching approaches and terminal assessments (Ali et al., 2018). Therefore, it is pertinent to explore the impacts of Pakistani university students' socioeconomic classes, gender, disciplines of study, and duration of university education experience on their learning approaches. Hence, the current study has the following objectives:

Objective 1: To find direct impacts of universitystudents' socioeconomic classes, gender, disciplines of study, and duration of university education experience on their learning approaches.

Objective 2: To find the total effects of university students' socioeconomic classes, gender, disciplines of study, and duration of university education experience on their learning approaches.

According to the stated objectives, the following hypotheses were postulated:

Hypothesis 1: There will be significant direct impacts on university students' socioeconomic

classes, gender, disciplines of study, and duration of university education experience on their learning approaches.

Hypothesis 2: There will be significant total effects on university students' socioeconomic classes, gender, disciplines of study, and duration of university education experience on their learning approaches.

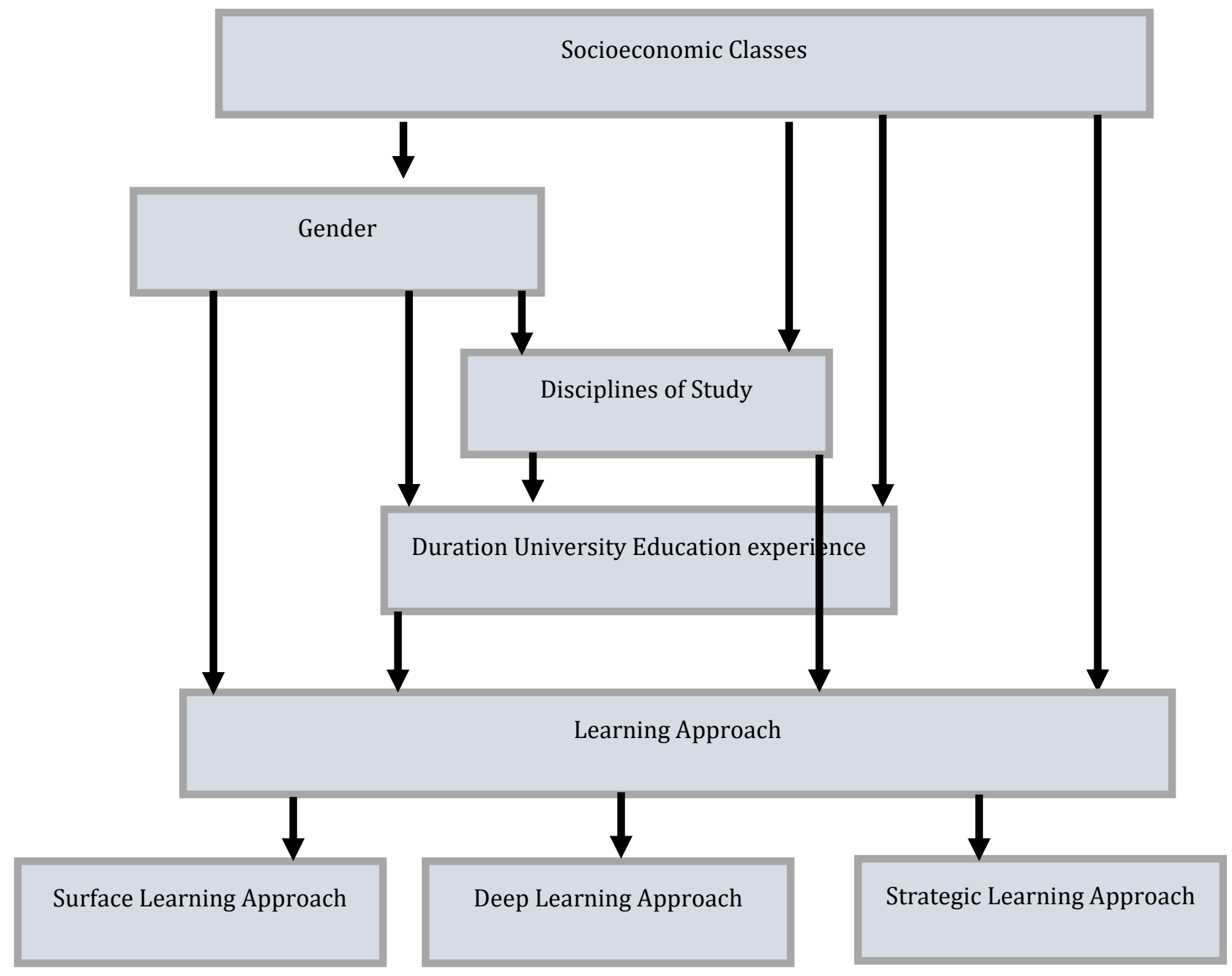

Figure 1. Conceptual Framework.

Source: The figure is drawn by the author after literature review. 


\section{DATA DESCRIPTION}

\section{Sample}

The researchers choose convenient sampling techniques from different non-probability sampling techniques to identify and select the sample of this study. The researchers decided the appropriate minimum sample size to run PLS-SEM analysis based on the ten times rule recommended by Hair et al. (2017). The study participants were 862 students from different academic departments of the Islamia University of Bahawalpur, Bahawalnagar campus. The sample consisted of 488 ( 56.6 percent) female students and 374 (43.4 percent) male students, and the average age of 89 percent of university students in the sample was 18-25 years. The sample consisted of 441(52.2 percent) participants from rural and 421 (48.8 percent) urban residential backgrounds. The composition of the sample consisted of students from departments of Biology (12 percent), Computer Sciences (27 percent), Educational Sciences (10.8 percent), English literature and Linguistics (25.2 percent), Mathematics (7.7 percent), and Sports Sciences (17.2 percent). In comparison, 26 percent of students were in the first year, 11.5 percent in second year, 31.7 percent in third year, and 22.4 percent in their fourth year of undergraduate degree programs. There were 8.4 percent students from postgraduate programs. The Google form link was shared with students through social media, and students voluntarily filled the form.

\section{Data Collection}

The researchers used the revised short version of the Approaches and Study Skills Inventory for Students (ASSIST) (Entwistle, 1997) to identify students' learning approaches in this study. This instrument classifies students' learning approaches into three types: deep, surface, and strategic. The original short version of ASSIST has 18 items to determine three learning approaches. However, 12 items were found reliable and valid to measure three learning approaches in this study. The students were advised to think about their particular courses and record their agreements to given statements. The students chose an appropriate option from five provided options against each statement. The five-point agreement scale included agree $=5$, somewhat agree $=4$, unsure $=3$, somewhat disagree $=2$, and disagree $=1$. The students' socioeconomic classes were calculated by scoring their self-reported parental occupations and parental education. The scoring criteria used for parental occupation and parental education was adapted from Kuppuswamy's Socioeconomic scale (Sharma, 2017). The sum of parental occupation and parental education scores was used to identify students' relevant socioeconomic classes. In line with Kuppuswamy's Socioeconomic scale (Sharma, 2017), the sample in this study comprises lower, upper-lower, and lowermiddle socioeconomic classes. The predefined possible categories for gender, the discipline of study, and duration of university education experience were provided in an online Google form. Consequently, university students selected their appropriate options from these categories to record their gender, discipline of study, and duration of university education experience.

\section{Data Analysis}

Socioeconomic class is a categorical variable. Therefore, the students' socioeconomic classes were converted into dummy variables. The presence of socioeconomic class was given the value 1 , and absence was given value 0 . Likewise, different disciplines of the study were transformed into dummy variables. The presence of the particular discipline of study was given the value 1 , and absence was given value 0 . The differences in mean scores in students' different learning approaches were calculated by SPSS. The measurement model analysis and path analysis were carried out with the help of Smarpls2.

\section{RESULTS}

Figure No.2 and Table Nos. 1, 2, 3, and 4 show the measurement and structural model analysis results. The results of measurement model analysis are shown in Table No. 1. The original learning approaches section of ASSIST (short version) (Entwistle, 1997) has 18 items to measure three latent variables; surface, strategic and deep learning approaches. In this study, the researchers dropped six items because these items contributed to low average variance extracted and low reliability. Consequently, 12 items were loaded across three latent variables in this study (Table No. 1, Figure No. 2 ). These item loadings on latent variables are significant, and these loadings are above the 0.5 value. The values of composite reliability and Cronbachs Alpha are above 0.7. Furthermore, the 
average variance extracted is above 0.5 for each latent variable. Hence, the item loadings, composite reliability values, Cronbachs Alpha values, and average variance extracted fall in the accepted and recommended range(Hair et al., 2014).

Table1. Measurement Model Analysis.

Latent Variable Loadings, Validity and Reliability

\begin{tabular}{|c|c|c|c|c|c|}
\hline \multirow{3}{*}{$\begin{array}{l}\text { Factor } \\
\text { Strategic } \\
\text { Learning } \\
\text { Approach }\end{array}$} & Items & Item Loadings & Cronbachs Alpha & Composite Reliability & AVE \\
\hline & LA3 & $0.672^{* *}$ & \multirow{4}{*}{0.70} & \multirow{4}{*}{0.80} & \multirow{4}{*}{0.51} \\
\hline & LA13 & $0.663^{* *}$ & & & \\
\hline \multirow[t]{2}{*}{ Approach } & LA5 & $0.761^{* *}$ & & & \\
\hline & LA9 & $0.767^{* *}$ & & & \\
\hline \multirow{4}{*}{$\begin{array}{l}\text { Surface } \\
\text { Learning } \\
\text { Approach }\end{array}$} & LA1 & $0.693^{* *}$ & \multirow[t]{4}{*}{0.71} & \multirow[t]{4}{*}{0.81} & \multirow[t]{4}{*}{0.52} \\
\hline & LA16 & $0.757^{* *}$ & & & \\
\hline & LA4 & $0.726^{* *}$ & & & \\
\hline & LA8 & $0.727^{* *}$ & & & \\
\hline \multirow{4}{*}{$\begin{array}{l}\text { Deep } \\
\text { Learning } \\
\text { Approach }\end{array}$} & LA10 & $0.693^{* *}$ & \multirow[t]{4}{*}{0.74} & \multirow[t]{4}{*}{0.83} & \multirow[t]{4}{*}{0.55} \\
\hline & LA12 & $0.789 * *$ & & & \\
\hline & LA17 & $0.752 * *$ & & & \\
\hline & LA2 & $0.738^{* *}$ & & & \\
\hline
\end{tabular}

Source:Data of this study.

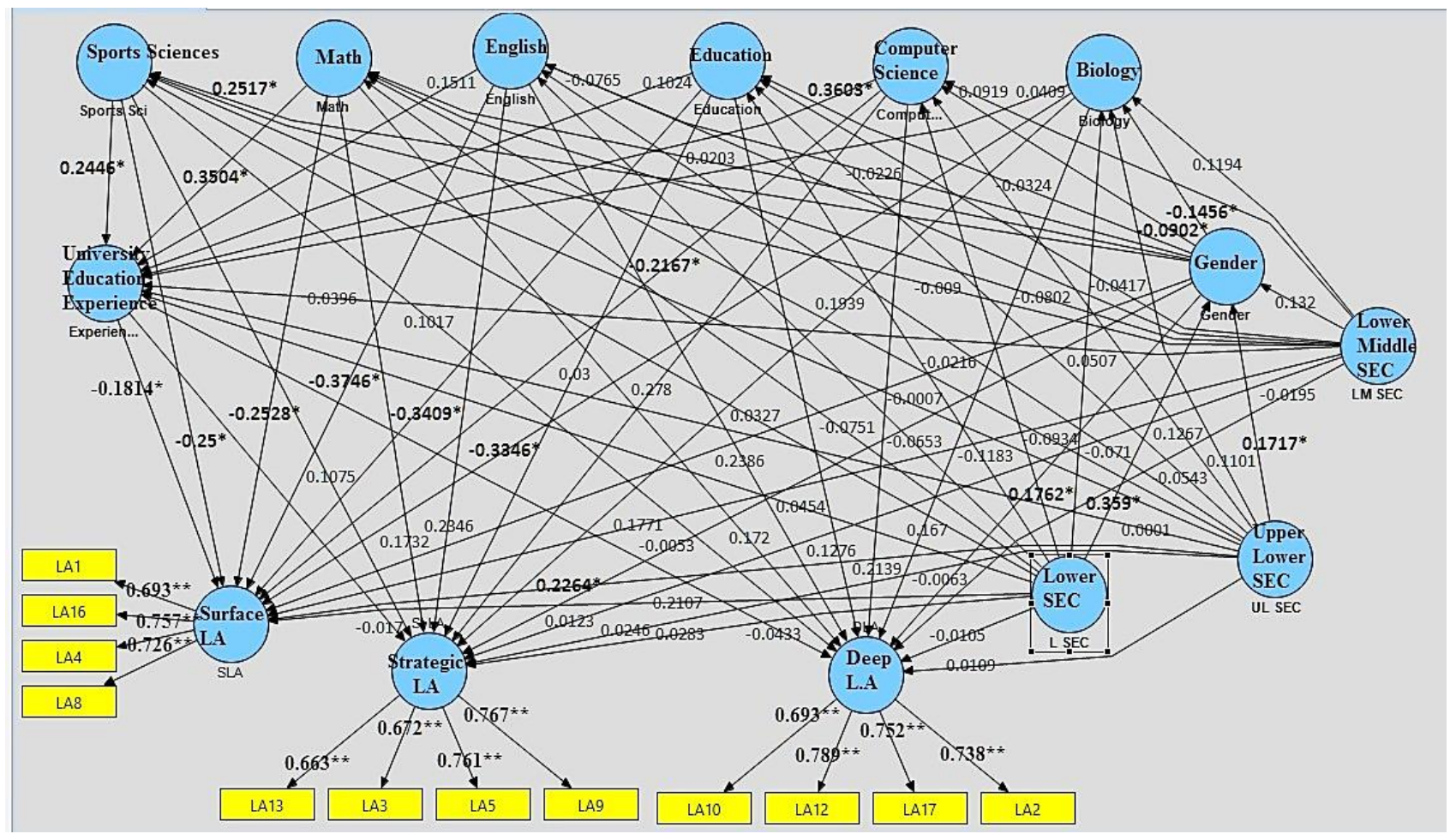

Figure 2. Measurement and Structural Model Analysis.

Source:Data of this study.

According to Fornell-Larcker criterion (Henseler et al., 2016), the latent variables in the measurement model have discriminant validity because highlighted values (square root of average variance extracted) are higher than the latent variables relationships with other latent variables in the measurement model (Table No.2). 
Table 2. Fornell-Larcker Criterion.

\begin{tabular}{|c|c|c|c|c|c|c|c|c|c|c|c|c|c|c|c|}
\hline \multicolumn{16}{|c|}{ Discriminant Validity Analysis } \\
\hline & & 1 & 2 & 3 & 4 & 5 & 6 & 7 & 8 & 9 & 10 & 11 & 12 & 13 & 14 \\
\hline 1 & Biology & 1 & & & & & & & & & & & & & \\
\hline 2 & Computer Science & -0.2 & 1 & & & & & & & & & & & & \\
\hline 3 & Deep LA & 0.02 & 0.00 & 0.74 & & & & & & & & & & & \\
\hline 4 & Education & -0.1 & -0.2 & -0.0 & 1 & & & & & & & & & & \\
\hline 5 & English & -0.2 & -0.3 & 0.05 & -0.2 & 1 & & & & & & & & & \\
\hline 6 & Experience & -0.1 & 0.15 & -0.0 & -0.0 & -0.1 & 1 & & & & & & & & \\
\hline 7 & Gender & -0.1 & -0.0 & -0.0 & -0.0 & -0.0 & 0.02 & 1 & & & & & & & \\
\hline 8 & L SEC & -0.0 & 0.04 & -0.0 & -0.0 & 0.00 & 0.06 & 0.20 & 1 & & & & & & \\
\hline 9 & LM SEC & 0.06 & -0.0 & -0.0 & 0.03 & -0.0 & -0.0 & -0.0 & -0.4 & 1 & & & & & \\
\hline 10 & Math & -0.1 & -0.1 & 0.04 & -0.1 & -0.1 & 0.21 & 0.02 & 0.01 & -0.0 & 1 & & & & \\
\hline 11 & Surface LA & -0.0 & 0.14 & 0.26 & -0.0 & -0.0 & -0.1 & 0.00 & 0.01 & -0.0 & -0.0 & 0.72 & & & \\
\hline 12 & Sports Science & -0.1 & -0.2 & -0.0 & -0.1 & -0.2 & 0.03 & 0.25 & 0.08 & -0.0 & -0.1 & 0.04 & 1 & & \\
\hline 13 & Strategic LA & 0.04 & 0.08 & 0.66 & -0.1 & 0.03 & 0.00 & -0.0 & 0.01 & -0.0 & 0.04 & 0.32 & -0.0 & 0.71 & \\
\hline 14 & UL SEC & 0.04 & -0.0 & 0.03 & 0.03 & 0.00 & -0.0 & -0.0 & -0.5 & -0.4 & -0.0 & 0.03 & -0.0 & 0.00 & 1 \\
\hline
\end{tabular}

Source: Data of the Study.

The significant and insignificant path coefficients are presented in Table No.3. The lower and lower-middle socioeconomic classes have no significant direct impact on students' learning approaches. Only the upper-lower socioeconomic class has a significant positive direct impact on students' surface learning approach. In the case of relationships between socioeconomic classes and gender, the lower and upper-lower socioeconomic classes have meaningful positive direct relationships with the gender. In this study, the male students are likely to be from lower and upper lower socioeconomic classes. The lower socioeconomic class students are most likely to study Computer Science subjects. About gender and disciplines of study, the Sports Sciences discipline seems male-gendered, whereas Biology and Computer Science disciplines seem female gendered. Biology, Computer Science, Education, English, Mathematics, and Sports Sciences have a direct negative impact on students' surface learning approach. However, this direct negative impact is more substantial in students of English and relatively weaker in students of Computer Science. The deep and strategic learning approaches do not seem to be related to disciplines of study. The duration of university education experience has a significant positive relationship with Computer Science, Mathematics, and Sports Sciences. Hence, the most senior students in the sample were from Computer Science, Mathematics, and Sports Sciences. The duration of the university education experience has a direct negative impact on the surface learning approach. 
Table 3. Direct Effects of Variables in Model.

Path Analysis

\begin{tabular}{|c|c|c|}
\hline Hypotheses & $\begin{array}{c}\text { Path } \\
\text { Coefficients }\end{array}$ & $\begin{array}{c}\mathrm{T} \\
\text { Statistics }\end{array}$ \\
\hline L SEC $\rightarrow>$ DLA & -0.0105 & 0.0869 \\
\hline L SEC -> SLA & 0.2107 & 1.9077 \\
\hline L SEC $->$ St LA & 0.0283 & 0.2664 \\
\hline UL SEC -> DLA & 0.0109 & 0.0881 \\
\hline UL SEC $->$ SLA & 0.2264 & $2.091^{*}$ \\
\hline UL SEC -> St LA & 0.0246 & 0.2334 \\
\hline LM SEC -> DLA & -0.0195 & 0.173 \\
\hline LM SEC -> SLA & 0.1771 & 1.7943 \\
\hline LM SEC -> St LA & 0.0123 & 0.1247 \\
\hline L SEC $->$ Gender & 0.359 & $4.6226^{*}$ \\
\hline UL SEC -> Gender & 0.1717 & $2.1799 *$ \\
\hline LM SEC -> Gender & 0.132 & 1.8305 \\
\hline L SEC -> Biology & 0.0507 & 0.6504 \\
\hline L SEC -> Computer Sci & 0.1762 & $2.0365^{*}$ \\
\hline L SEC -> Education & -0.1183 & 1.087 \\
\hline L SEC $->$ English & -0.0653 & 0.6488 \\
\hline L SEC -> Math & -0.0751 & 0.6534 \\
\hline L SEC -> Sports Sci & 0.0327 & 0.3675 \\
\hline UL SEC -> Biology & 0.1101 & 1.3882 \\
\hline UL SEC -> Computer Sci & 0.1267 & 1.4969 \\
\hline UL SEC -> Education & -0.0543 & 0.4904 \\
\hline UL SEC -> English & -0.071 & 0.701 \\
\hline UL SEC -> Math & -0.0934 & 0.8035 \\
\hline UL SEC -> Sports Sci & -0.0007 & 0.0077 \\
\hline LM SEC -> Biology & 0.1194 & 1.618 \\
\hline LM SEC -> Computer Sci & 0.0919 & 1.1836 \\
\hline LM SEC -> Education & -0.0417 & 0.4111 \\
\hline LM SEC -> English & -0.0765 & 0.8226 \\
\hline LM SEC -> Math & -0.0802 & 0.7511 \\
\hline LM SEC -> Sports Sci & -0.009 & 0.1104 \\
\hline L SEC -> Experience & 0.0454 & 0.4349 \\
\hline UL SEC -> Experience & 0.0001 & 0.0012 \\
\hline LM SEC -> Experience & 0.0396 & 0.4187 \\
\hline Gender -> DLA & -0.0063 & 0.16 \\
\hline Gender -> SLA & -0.0216 & 0.6492 \\
\hline Gender -> St LA & -0.0053 & 0.1496 \\
\hline Gender -> Biology & -0.1456 & $5.1529^{*}$ \\
\hline Gender -> Computer Sci & -0.0902 & $2.7511^{*}$ \\
\hline Gender -> Education & -0.0324 & 1.032 \\
\hline
\end{tabular}

\begin{tabular}{lrr}
\hline Gender -> English & -0.0226 & 0.6975 \\
\hline Gender -> Math & 0.0203 & 0.6449 \\
\hline Gender -> Sports Sci & 0.2517 & $8.3235^{*}$ \\
\hline Biology -> DLA & 0.167 & 1.2701 \\
\hline Biology -> SLA & -0.3346 & $5.1858^{*}$ \\
\hline Biology -> St LA & 0.1939 & 1.5261 \\
\hline Computer Sci -> DLA & 0.2139 & 1.1912 \\
\hline Computer Sci -> SLA & -0.2167 & $2.602^{*}$ \\
\hline Computer Sci -> St LA & 0.278 & 1.5999 \\
\hline Education -> DLA & 0.1276 & 0.9911 \\
\hline Education -> SLA & -0.3409 & $5.3929^{*}$ \\
\hline Education -> St LA & 0.03 & 0.2333 \\
\hline English -> DLA & 0.2386 & 1.4024 \\
\hline English -> SLA & -0.3746 & $4.7241^{*}$ \\
\hline English -> St LA & 0.2346 & 1.3911 \\
\hline Math -> DLA & 0.172 & 1.5089 \\
\hline Math -> SLA & -0.2528 & $4.3793^{*}$ \\
\hline Math -> St LA & 0.1732 & 1.5513 \\
\hline Sports Sci -> DLA & 0.1017 & 0.6748 \\
\hline Sports Sci -> SLA & -0.25 & $3.5346^{*}$ \\
\hline Sports Sci -> St LA & 0.1075 & 0.7037 \\
\hline Biology -> Experience & 0.0409 & 0.5211 \\
\hline Computer Sci -> & 0.3603 & $3.4786^{*}$ \\
Experience & & \\
\hline Education -> & 0.1024 & 1.3015 \\
Experience & & \\
\hline English -> Experience & 0.1511 & 1.4423 \\
\hline Math -> Experience & 0.3504 & $5.1074^{*}$ \\
\hline Sports Sci -> & 0.2446 & $2.6423^{*}$ \\
Experience & -0.0433 & 1.1015 \\
\hline Experience -> DLA & -0.1814 & $5.3857^{*}$ \\
\hline Experience -> SLA & -0.017 & 0.4311 \\
\hline Experience -> St LA & & P $<0.05 *^{*}$ \\
\hline & & \\
\hline & & \\
\hline
\end{tabular}

SEC=Socioeconomic Class, L SEC=Lower Socioeconomic class, UL SEC= Upper Lower Socioeconomic class, LM SEC= Lower Middle Socioeconomic Class, SLA=Surface Learning Approach, StLA=Strategic Learning Approach, DLA=Deep Learning Approach, Sci=Sciences

Source: Data of the Study.

The significant total effects of latent variables on learning approaches are present in Table no. 4. 
Table 4. Total Effects of Variables in Model

\begin{tabular}{|c|c|c|}
\hline \multicolumn{3}{|l|}{ Total Effects Analysis } \\
\hline Hypothesis & $\begin{array}{c}\text { Path } \\
\text { Coefficients }\end{array}$ & $\begin{array}{c}\mathrm{T} \\
\text { Statistics } \\
\end{array}$ \\
\hline \multicolumn{3}{|l|}{ SEC } \\
\hline L SEC -> DLA & -0.0189 & 0.1506 \\
\hline L SEC -> SLA & 0.2162 & $1.9719^{*}$ \\
\hline L SEC $->$ St LA & 0.0451 & 0.3848 \\
\hline UL SEC $->$ DLA & 0.0109 & 0.0858 \\
\hline UL SEC -> SLA & 0.2298 & $2.1328^{*}$ \\
\hline UL SEC -> St LA & 0.0406 & 0.3505 \\
\hline LM SEC -> DLA & -0.0237 & 0.2041 \\
\hline LM SEC -> SLA & 0.1761 & 1.7807 \\
\hline LM SEC $->$ St LA & 0.0218 & 0.2025 \\
\hline \multicolumn{3}{|l|}{ Gender } \\
\hline Gender -> DLA & -0.0313 & 0.8782 \\
\hline Gender -> SLA & -0.0061 & 0.1906 \\
\hline Gender $->$ St LA & -0.0347 & 1.0024 \\
\hline \multicolumn{3}{|l|}{ Disciplines of Study } \\
\hline Biology -> DLA & 0.1652 & 1.2451 \\
\hline Biology $->$ SLA & -0.3421 & $5.3301^{*}$ \\
\hline Biology -> St LA & 0.1932 & 1.5176 \\
\hline Computer Sci -> DLA & 0.1983 & 1.1045 \\
\hline Computer Sci -> SLA & -0.2821 & $3.47^{*}$ \\
\hline $\begin{array}{l}\text { Computer Sci } \rightarrow \text { St } \\
\text { LA }\end{array}$ & 0.2719 & 1.5675 \\
\hline Education -> DLA & 0.1232 & 0.9521 \\
\hline Education -> SLA & -0.3595 & 5.6487* \\
\hline Education -> St LA & 0.0283 & 0.2198 \\
\hline English -> DLA & 0.232 & 1.3517 \\
\hline English -> SLA & -0.402 & $5.1061^{*}$ \\
\hline English -> St LA & 0.2321 & 1.3725 \\
\hline Math -> DLA & 0.1569 & 1.3962 \\
\hline Math -> SLA & -0.3163 & $5.5879^{*}$ \\
\hline Math -> St LA & 0.1673 & 1.5193 \\
\hline Sports Sci -> DLA & 0.0911 & 0.6028 \\
\hline Sports Sci -> SLA & -0.2944 & $4.2215^{*}$ \\
\hline Sports Sci -> St LA & 0.1034 & 0.6786 \\
\hline $\mathrm{P}<0.05=*$ & & \\
\hline
\end{tabular}

SEC=Socioeconomic Class, L SEC=Lower Socioeconomic class, UL SEC $=$ Upper Lower Socioeconomic class, LM SEC=Lower Middle Socioeconomic Class, SLA=Surface Learning Approach, StLA=Strategic Learning Approach, DLA=Deep Learning Approach, Sci=Sciences

Source: Data of the Study.

The students' lower socioeconomic class has no significant direct impact on students' surface learning approach. However, its total effect through other latent variables in the model is substantial and positive. Apart from the direct significant positive impact of upper-lower socioeconomic class on students' surface learning approaches, the upperlower socioeconomic class has a significant positive total effect on students' surface learning approach. In comparison, the students' gender has no significant direct or total effect on students' learning approaches. However, the students' disciplines of study have a substantial direct and total impact on students' surface learning approach. Likewise, the subject areas of Biology, Computer Science, Education, English, Math, and Sports Sciences have significant negative total effects on students' surface learning approach.

\section{DISCUSSION}

This study highlighted the importance of university students' socioeconomic classes, gender, disciplines of study, and duration of university education experience in developing a surface learning approach. The superior socioeconomic class has no significant impact on students' surface learning approach. At the same time, the less superior socioeconomic classes have meaningful positive relationships with students' surface learning approach. The available literature acknowledges positive relationships of less superior socioeconomic classes with students' surface learning approach (Ali \& Bakar, 2019).

The students of less superior socioeconomic class have immature learning beliefs because their parents cannot provide a home environment favorable for developing sophisticated learning beliefs (Cano \& Cardelle-Elawar, 2008). Consequently, the students' naive beliefs in learning produce a surface learning approach (Chiou et al., 2013).

It was anticipated that students' gender would impact their learning approaches. In this study, the variable gender did not contribute to students' learning approaches. Although, different studies have corroborated a strong tendency for surface learning approach in male students compared to female students (Chiou et al., 2011; Ismail et al., 2013). Also, the results of different studies have indicated that female students are more likely to have a surface learning approach than male students (Sadler-Smith, 1996). In contrast, some researchers have found no gender differences in deep and surface learning approaches among male and female students 
(Zeegers, 2001). Hence, there is inconclusive evidence about gender differences in students' surface and deep learning approaches. Different populations, different teaching-learning environments, social and cultural differences can be reasons for inconsistent findings in the literature.

This study found a significant negative impact of different disciplines of study on students' surface learning approach. However, the fields of the study appear to have no impact on deep and strategic learning approaches. The negative effects of disciplines of study on students' surface learning approach vary in degree of strength. The English Language and Literature, Education, and Biology disciplines have moderate negative relationships with the surface learning approach. Whereas the fields of Computer Science, Sports Sciences, and Mathematics have weak negative associations with the surface learning approach. In other words, students of English Language and Literature, Education and Biology have less inclination for surface learning approach than students of Computer Science, Sports Sciences and Mathematics. These findings affirm previous findings that the students of Humanities, Social Sciences, Languages, and Ethnic studies have less inclination for surface learning approach than students of Business, Math, Technology, Computing, and Physical Sciences (Ismail et al., 2013; Nelson Laird et al., 2008; Ullah et al., 2013).

Another finding of this study is that the duration of experience in university education has a significant negative association with students' surface learning approach. However, the previous results show that this relationship is not straightforward. Usually, the students in their first and last years of study have a strong tendency for a surface learning approach than students of second and third years in a four-year degree program (Byrne et al., 2004; Ismail et al., 2013). The students in different years of study adopt different learning approaches because of their course content requirements, workload, course and assessment perceptions (Byrne et al., 2004; Entwistle \& Tait, 1990; Price et al., 2011).

\section{CONCLUSION}

The students' socioeconomic classes, disciplines of study, and duration of university education experience have significant effects on their learning approaches. Although the impact of socioeconomic classes on the surface learning approach may be positive, disciplines of study and students' university education experience can decrease the positive effect of socioeconomic classes on students' surface learning approach. Even though gender plays a significant role in the selection of disciplines of study, however, there are no significant differences in learning approaches among male and female students of different fields. The naive epistemological beliefs, less complex conceptions of learning, and low parental education are the causes of the high surface learning approach in students from the less superior socioeconomic background. The students of the first semester are more likely to be surface learners. However, the students' perceptions of the coursework as a heavy workload constrain them to adopt a deep learning approach even in the last semester of their study. The students' similar experiences of teaching methods, teaching approaches, assessments, and course perception produce insignificant differences in students' surface, deep and strategic learning approaches.

\section{LIMITATIONS OF THE STUDY}

The study had some limitations. The researchers used only relative socioeconomic class indicators of parental education and profession to determine students' socioeconomic classes. Therefore, these socioeconomic classes are not an alternative to family income. The study included only one campus of the Islamia University of Bahawalpur. The campus location is unique because it is located in an underdeveloped district of Punjab, lacking infrastructure and industrialization. The commonly used teaching method in this campus is lecture, and teacher-centered teaching approaches are common prevailing approaches.

\section{FUTURE RESEARCH RECOMMENDATIONS}

It is recommended that upcoming studies evaluate teaching methods, teacher-student interactions, and students' workloads to develop a deep learning approach in Pakistani Students. Furthermore, there is the need to carry out longitudinal studies to understand the development of learning approaches in students of different socioeconomic classes across 
their different years and stages of education. Additionally, the qualitative research approach is recommended to explore different learning approaches in Pakistani students of different socioeconomic classes, educational institutions, and academic levels. Future studies should probe Pakistani teachers' learning approaches to understand teachers' role in the development of students' learning approaches.

\section{POLICY IMPLICATIONS}

The teacher-training institutions should frequently train teachers to use modern technology in classrooms and apply student-centered teaching methods to enhance students' inclination for a deep learning approach and discourage the tendency for a surface learning approach. Additionally, the education policy should be formulated to guide and support teachers in using student-centered teaching methods, applying the conceptual change and student-focus approaches, and enhancing the quality of teacher-student interactions. There should be student-centered teaching methods, small class sizes, and a problem-based curriculum to instigate students' deep learning approach. Personal attributes and students' beliefs also influence the development of learning approaches. Therefore, these should be appraised during different stages of education and intervened if these are immature.

\section{REFERENCES}

Ali, R., \& Bakar, A. (2019). The Probability to Memorize and Understand Textbook Information: Socioeconomic Class as the Predictor for Cognitive Processing Strategies in Pakistani Education System. Pakistan Journal of Social Sciences (PJSS), 39(1).

Ali, R., Khurshid, K., Shahzad, A., Hussain, I., \& Bakar, Z. A. (2018). Nature of Conceptions of Learning in a Collectivistic Society: A Qualitative Case Study of Pakistan. EURASIA Journal of Mathematics, Science and Technology Education, 14(4), 1175-1187.

American Psychological Association. (2019). Socioeconomic Status. Retrieved from https://www.apa.org/topics/socioeconomicstatus

Beausaert, S. A. J., Segers, M. S. R., \& Wiltink, D. P. A.
(2013). The influence of teachers' teaching approaches on students' learning approaches: the student perspective. Educational Research, 55(1), 1-15.

Biggs, J. (1998). Learning from the Confucian heritage: so size doesn't matter? International Journal of Educational Research, 29(8), 723738.

Biggs, J. B. (1987a). Learning Process Questionnaire Manual, Student Approaches to learning and Studying. Hawthorn: Australiian Council of Educational Research: Retrieved from http://files.eric.ed.gov/fulltext/ED308199.pdf.

Biggs, J. B. (1987b). Study Process Questionnaire Manual. Student Approaches to Learning and Studying. Hawthorn: Australian Council For Educational Research Retrieved from http://files.eric.ed.gov/fulltext/ED308200.pdf.

Burnett, P. C., \& Proctor, R. M. (2002). Elementary School Students' Learner Self-Concept, Academic Self-Concepts and Approaches to Learning. Educational Psychology in Practice, 18(4), 325-333.

Byrne, M., Finlayson, O., Flood, B., Lyons, O., \& Willis, P. (2010). A comparison of the learning approaches of accounting and science students at an Irish university. Journal of Further and Higher Education, 34(3), 369-383.

Byrne, M., Flood, B., \& Willis, P. (2004). Using the student learning framework to explore the variation in academic performance of European business students. Journal of Further and Higher Education, 28(1), 67-78.

Byrne, M., Flood, B., \& Willis, P. (2009). An InterInstitutional Exploration of the Learning Approaches of Students Studying Accounting. International Journal of Teaching and Learning in Higher Education, 20(2), 155-167.

Campbell, J., Smith, D., Boulton-Lewis, G., Brownlee, J., Burnett, P. C., Carrington, S., \& Purdie, N. (2001). Students' Perceptions of Teaching and Learning: The influence of students' approaches to learning and teachers' approaches to teaching. Teachers and Teaching, $7(2), 173-187$.

Cano, F. (2005). Epistemological beliefs and approaches to learning: their change through secondary school and their influence on 
academic performance. BrJ Educ Psychol, 75(Pt 2), 203-221.

Cano, F., \& Cardelle-Elawar, M. (2008). Family Environment, Epistemological Beliefs, Learning Strategies, and Academic Performance: A Path Analysis. In M. Khine (Ed.), Knowing, Knowledge and Beliefs (pp. 219-239): Springer Netherlands.

Case, J. M., \& Marshall, D. (2009). Approaches to Learning. In Malcolm Tight, Ka Ho Mok, Jeroen Huisman, \& C. Morphew (Eds.), The Routledge International Handbook of Higher Education (pp. 9-21). New York,: Routledge.

Cetin, B. (2016). Approaches to learning and age in predicting college students' academic achievement. Journal of College Teaching \& Learning, 13(1), 21-28.

Chamorro-Premuzic, T., \& Furnham, A. (2008). Personality, intelligence and approaches to learning as predictors of academic performance. Personality and Individual Differences, 44(7), 1596-1603.

Chamorro-Premuzic, T., \& Furnham, A. (2009). Mainly Openness: The relationship between the Big Five personality traits and learning approaches. Learning and Individual Differences, 19(4), 524-529.

Chin, C., \& Brown, D. E. (2000). Learning in Science: A Comparison of Deep and Surface Approaches. Journal of Research in Science Teaching, 37(2), 109-138.

Chiou, G.-L., Lee, M.-H., \& Tsai, C.-C. (2013). High school students' approaches to learning physics with relationship to epistemic views on physics and conceptions of learning physics. Research in Science \& Technological Education, 31(1), 1-15.

Chiou, G.-L., Liang, J.-C., \& Tsai, C.-C. (2011). Undergraduate Students' Conceptions of and Approaches to Learning in Biology: A study of their structural models and gender differences. International Journal of Science Education, 34(2), 167-195.

Diseth, Å., \& Kobbeltvedt, T. (2010). A mediation analysis of achievement motives, goals, learning strategies, and academic achievement. British Journal of Educational Psychology, 80(4), 671-687.
Douglas, H. E., Rubin, M., Scevak, J., Southgate, E., Macqueen, S., \& Richardson, J. T. E. (2020). Older Women, Deeper Learning: Age and Gender Interact to Predict Learning Approach and Academic Achievement at University. Frontiers in Education, 5, 158. Retrieved from https://www.frontiersin.org/article/10.3389/f educ. 2020.00158

Duff, A. (2004). The Revised Approaches to Studying Inventory (RASI) and its Use in Management. Active Learning in Higher Education 2004 5(56), DOI: $10.1177 / 1469787404040461$

Edmunds, R., \& Richardson, J. T. (2009). Conceptions of learning, approaches to studying and personal development in UK higher education. Br J Educ Psychol, 79(Pt 2), 295-309.

Egenti, H. N. (2012). Relationships of approaches to studying, metacognition, and intellectual development of general chemistry students. (3533578 Ph.D. Thesis), University of North Texas, United States,

Ensminger, M. E., \& Fothergill, K. (2003). A decade of measuring SES: what it tells us and where to go from here In: Bornstein M, Bradley R,. In B. M \& Bradley R (Eds.), Socioeconomic Status, Parenting, and Child Development, Monographs in parenting series. New Jersey: Lawrence Erlbaum Associates, Inc.

Entwistle, N., Hanley, M., \& Hounsell, D. (1979). Identifying distinctive approaches to studying. Higher Education, 8(4), 365-380.

Entwistle, N., J. (1997). The Approaches and Study Skills Inventory for Students (ASSIST). Edinburgh: Centre for Research on Learning and Instruction, University of Edinburgh.

Entwistle, N., \& Tait, H. (1990). Approaches to learning, evaluations of teaching, and preferences for contrasting academic environments. Higher Education, 19(2), 169194.

Evans, C., \& Vermunt, J. D. (2013). Styles, approaches, and patterns in student learning. British Journal of Educational Psychology, 83(2), 185195.

Hair, J., F., Hult, G., Tomas, M., Ringle, C., M., \& Sarstedt, M. (2014). Primer on Partial Least Squares Structural Equation Modeling (PLSSEM). California, USA: SAGE Publications, Inc. 
Hair, J., F., Hult, G., Tomas, M., Ringle, C., M., \& Sarstedt, M. (2017). Primer on Partial Least Squares Structural Equation Modeling (PLSSEM). California, USA: SAGE Publications, Inc.

Heikkilä, A., \& Lonka, K. (2006). Studying in higher education: students' approaches to learning, self-regulation, and cognitive strategies. Studies in Higher Education, 31(1), 99-117.

Henseler, J., Hubona, G., \& Ray, P. A. (2016). Using PLS path modeling in new technology research:updated guidelines. Industrial Management \& Data Systems, 116(1), 2-10.

Ismail, H., Hassan, A., Muhamad, M. M., Wan Zah, W. A., \& Konting, M. M. (2013). Epistemological Belief and Learning Approaches of Students in Higher Institutions of Learning in Malaysia. International Journal of Instruction, 6(1), 139150.

Kayali, Z., Abdulwali, F. K., Peeran, A. A., Obad, A. S., \& Shareef, M. A. (2017). Impact of Learning Approaches on Academic Performance of Preclinical Medical Students: Superficial Vs Deep. The FASEB Journal, 31, 510-576.

Kember, D. (1996). The intention to both memorise and understand: Another approach to learning? Higher Education, 31(3), 341-354.

Kember, D., \& Gow, L. Y. N. (1990). Cultural Specificity of Approaches to Study British Journal of Educational Psychology, 60(3), 356-363.

Kember, D., Jamieson, Q., Pomfret, M., \& Wong, E. T. (1995). Learning approaches, study time and academic performance. Higher Education, 29(3), 329-343.

Kreber, C. (2003). The Relationship between Students' Course Perception and their Approaches to Studying in Undergraduate Science Courses: A Canadian experience. Higher Education Research \& Development, 22(1), 57-75.

Nelson Laird, T., F, Shoup, R., Kuh, G., D, \& Schwarz, M., J. (2008). The Effects of Discipline on Deep Approaches to Student Learning and College Outcomes. Research in Higher Education, 49(6), 469-494.

Price, L., Richardson, J. T. E., Robinson, B., Ding, X., Sun, X., \& Han, C. (2011). Approaches to studying and perceptions of the academic environment among university students in
China. Asia Pacific Journal of Education, 31(2), 159-175.

Richardson, J. E. (1994). Cultural specificity of approaches to studying in higher education: A literature survey. Higher Education, 27(4), 449468.

Richardson, J. T. (2010). Conceptions of learning and approaches to studying among White and ethnic minority students in distance education. BrJ Educ Psychol, 80(Pt 4), 535-556.

Rosário, P., Núñez, J., Ferrando, P., Paiva, M., Lourenço, A., Cerezo, R., \& Valle, A. (2013). The relationship between approaches to teaching and approaches to studying: a two-level structural equation model for biology achievement in high school. Metacognition and Learning, 8(1), 47-77.

Sadler-Smith, E. (1996). Approaches to Studying: age, gender and academic performance. Educational Studies, 22(3), 367-379.

Salamonson, Y., Weaver, R., Chang, S., Koch, J., Bhathal, R., Khoo, C., \& Wilson, I. (2013). Learning approaches as predictors of academic performance in first year health and science students. Nurse Education Today, 33(7), 729733.

Scouller, K. (1998). The influence of assessment method on students' learning approaches: Multiple choice question examination versus assignment essay. Higher Education, 35(4), 453-472.

Sharma, R. (2017). Update: Revised Kuppuswamy's Socioeconomic Status Scale: Explained and Updated. Indian Pediatrics, 54(15), 667-870.

Sirin, S. R. (2005). Socioeconomic Status and Academic Achievement: A Meta-Analytic Review of Research. Review of Educational Research, 75(3), 417-453.

Ullah, R., Richardson, J. T. E., \& Hafeez, M. (2013). Variations in perceptions of the learning environment and approaches to studying among university students in Pakistan. PROSPECTS, 43(2), 165-186.

Zeegers, P. (2001). Approaches to learning in science: A longitudinal study. British Journal of Educational Psychology, 71(1), 115-132. 
Publisher's note: EScience Press remains neutral with regard to jurisdictional claims in published maps and institutional affiliations. (c) (i)

Open Access This article is licensed under a Creative Commons Attribution 4.0 International License, which permits use, sharing, adaptation, distribution and reproduction in any medium or format, as long as you give appropriate credit to the original author(s) and the source, provide a link to the Creative Commons license and indicate if changes were made. The images or other third-party material in this article are included in the article's Creative Commons license, unless indicated otherwise in a credit line to the material. If material is not included in the article's Creative Commons license and your intended use is not permitted by statutory regulation or exceeds the permitted use, you will need to obtain permission directly from the copyright holder. To view a copy of this license, visit http://creativecommons.org/licenses/by/4.0/.

(C) The Author(s) 2021. 